\title{
Relation between Amino Acids Profiles and Recalcitrancy of Cell Growth or Salt Tolerance in Tissue and Protoplast Cultures of Three Mangrove Species, Avicennia alba, Bruguiera sexangula, and Sonneratia alba
}

\author{
Shinpei Tsuchiya ${ }^{1}$, Shinjiro Ogita ${ }^{2}$, Yoshifumi Kawana ${ }^{1}$, Tomoya Oyanagi ${ }^{1}$, Ai Hasegawa ${ }^{1}$, \\ Hamako Sasamoto ${ }^{1,3}$ \\ ${ }^{1}$ Graduate School of Environment and Information Sciences, Yokohama National University, Yokohama, Japan; ${ }^{2}$ Biotechnology \\ Research Center and Department of Biotechnology, Toyama Prefectural University, Toyama, Japan; ${ }^{3}$ Faculty of Environment and \\ Information Sciences, Yokohama National University, Yokohama, Japan. \\ Email: sasamoto@ynu.ac.jp
}

Received April 22 $2^{\text {nd }}, 2013$; revised May 23 ${ }^{\text {rd }}, 2013$; accepted June $15^{\text {th }}, 2013$

Copyright (C) 2013 Shinpei Tsuchiya et al. This is an open access article distributed under the Creative Commons Attribution License, which permits unrestricted use, distribution, and reproduction in any medium, provided the original work is properly cited.

\begin{abstract}
Amino acids profiles were investigated in tissues, cultured cells, i.e. callus or suspension cells, and their protoplasts of three mangrove species, Avicennia alba, Bruguiera sexangula, and Sonneratia alba. Original tissues of cultured cells of three mangrove species were cotyledons and hypocotyls, leaves, and cotyledons, respectively. In protoplasts isolated from cultured cells, glutamine and alanine were the major amino acids. Different contents of glycine, proline and serine were observed among protoplasts of three mangrove species. Large differences in the major amino acids were found among cultured cells and their protoplasts while no difference was found between callus and suspension cells independent of additional salt in culture medium. Protoplasts of original tissues, young leaves and cotyledons, contained alanine and glutamine and/or asparagine. In suspension cells of $B$. sexangula, total contents of amino acids were low while their protoplasts showed similar value as of other samples. Protoplasts of leaf and cotyledons of $A$. alba and cotyledons of A. lanata, A. marina and S. alba were also investigated. The total contents of amino acids and their profiles might be related to the recalcitrance for the growth and salt tolerance or halophilic nature of cells and basal media used for the maintenance of cell cultures or protoplast cultures of the mangrove species. This is the first report on callus induction from hypocotyls of $A$. alba.
\end{abstract}

Keywords: Amino Acid; Avicenniaceae; Callus Culture; Mangrove Plants; Protoplast Culture; Rhizophoraceae; Sonneratiaceae; Suspension Culture

\section{Introduction}

Mangrove plants, including more than 100 species of different families can be found in brackish water in tropical and subtropical regions [1,2]. Their halophilic or salt tolerance characteristics and adaptation to different osmotic conditions can serve as useful experimental systems to study mechanisms of salt tolerance. Information obtained will have potential application in improving plants' ability to tolerate higher salt levels in the future [3]. Tissue culture is a powerful tool to investigate the mechanisms of salt tolerance at the cellular and molecular levels. However, most mangrove plants remain recalcitrant for cell culture manipulations except for several species. In Sonneratiaceae, callus cultures have been obtained using pistils as explants [4] and suspension cells have successfully been obtained from cotyledons [5] of Sonneratia alba. In $S$. caseolaris, suspension cells were successfully generated from seedlings [6]. These cultures were maintained in the Murashige \& Skoog's (MS) basal medium [7], which is commonly used in tissue cultures of not only herbaceous plants but also in woody plants. Suspension culture of Bruguiera sexangula in Rhizophoraceae has been developed from leaf derived callus culture and sub-cultured more than 10 years in an amino acid (AA) basal medium [8]. For callus induction, the AA medium was preferred to MS [9]. In Avicenniaceae, suspension culture of Avicennia alba was induced from 
cotyledons and sub-cultured in a modified amino acid (mAA) medium [10]. In (m)AA medium, total nitrogen content of MS was reduced to $c a .1 / 3$ and $\mathrm{NO}_{3}^{-}$or $\mathrm{NH}_{4}^{+}$were replaced by amino acids [6,7]. Using cultured cells of three mangrove species, A. alba, B. sexangula and $S$. alba, the effects of sea salts on their growth were investigated and tolerance or halophilic nature were found $[10,11]$.

Protoplast culture of $B$. sexangula was the first species successfully generated for a mangrove species and the protoplast salt tolerance property was compared to a herbaceous plant and a non-mangrove woody plant [12]. The basal medium for protoplast culture of $B$. sexangula was MS, which was different from the AA media for the suspension cells. Recently, some success in protoplasts cultures of $A$. alba suspension cells and $S$. alba cotyledons were developed using the mAA and MS basal medium, respectively, and salt tolerant or halophilic nature of protoplasts were found $[13,14]$.

Amino acids can have an important role to play in the development and establishment of a culture system. Ogita et al. [15] reported the successful maintenance of a recalcitrant conifer callus culture through measurement of endogenous levels of amino acids and application of a specific amino acid, glutamine, in the basal medium. In this report, in order to determine whether amino acids can play a role in the establishment of mangrove cell cultures, the endogenous amino acid compositions of callus, suspension cells, and protoplasts of $A$. alba, B. sexangula and $S$. alba were investigated. The results were compared to the amino acid profiles of protoplasts of the original tissues. In addition, the amino acid contents of leaf and cotyledons of $A$. lanata and A. marina were also determined as these species are still very recalcitrant for callus proliferation.

\section{Materials and Methods}

\subsection{Plant Materials}

Crypto-viviparous seeds of Avicennia alba and A. lanata were collected in Thailand, and seeds of A. marina and fruits of Sonneratia alba were collected from IriomoteIsland, Okinawa Japan. Seeds of S. alba were aseptically germinated and the cotyledons were used as explants for the generation of callus and suspension cultures [5]. For Avicennia species, germinated seedlings were stored in tap water [13] and were used for tissue cultures or protoplasts isolation after sterilization. Young leaf of $A$. alba was obtained from a seedling of $10 \mathrm{~cm}$ height which grew in tap water in a flask for 5 months.

\subsection{Tissue Cultures: Callus Induction}

Maintaining callus cultures of $A$. alba were induced from seedling cotyledons and hypocotyls. The seedlings were maintained in sterile tap water (changing occasionally) for 5 months after seed sterilization with $2 \% \mathrm{NaClO}$ solution for $40 \mathrm{~min}$. Basal medium was the modified amino acid medium (mAA), in which the glycine content was decreased to $1 / 10$ of AA medium [9], containing $1 \mu \mathrm{M}$ each of 2,4-dichlorophenoxyacetic acid (2,4-D) and thidiazuron (TDZ) and $3 \%$ sucrose [10]. The medium $\mathrm{pH}$ was adjusted to 6.3 with $\mathrm{NaOH}$ before autoclaving at $120^{\circ} \mathrm{C}, 20 \mathrm{~min}$. They were sub-cultured at $1-2$ months intervals.

Suspension culture of Bruguiera sexangula [8-9] was sub-cultured at 2 - 3 weeks intervals in liquid AA medium containing $0.02 \mu \mathrm{M}$ of $2,4-\mathrm{D}$ and $2 \mu \mathrm{M}$ of $N$-(2-chloro-4pyridyl)- $N$ '-phenylurea (CPPU, Sigma) and 3\% sucrose. Fresh medium (after autoclaving) and used medium after 20 days of culture were filter-sterilized $(0.22 \mu \mathrm{m})$ and kept under sterile condition before amino acid analysis.

$S$. alba suspension culture and callus cultures were originated from cotyledons $[5,11]$. They were sub-cultured during 3 to 5 years at 2 weeks intervals (suspension cells) and one month intervals (callus) with MS basal medium containing $3 \%$ sucrose, $0.1 \mu \mathrm{M}$ of $2,4-\mathrm{D}$ with and without $50 \mathrm{mM}$ of $\mathrm{NaCl}$.

All cultures were incubated in the dark at $30^{\circ} \mathrm{C}$. Suspension culture was maintained in $20-40 \mathrm{~mL}$ medium in a $100 \mathrm{ml}$ flask on a rotary shaker at $100 \mathrm{rpm}$ speed. Callus culture was maintained on medium containing $0.8 \%$ agar (tissue culture grade, Wako chemical co. Ltd) using 6 or $9 \mathrm{~cm} \varphi$ petri dishes.

Fresh weights of tissue or callus, or wet weights of suspension cells $(10-20 \mathrm{mg})$ were measured before storing at $-80^{\circ} \mathrm{C}$.

\subsection{Protoplast Isolation}

Protoplasts were isolated from cotyledons of A. alba, A. lanata and A. marina by $1 \%$ or $2 \%$ each of Cellulase RS (Yakult) and Driselase 20 (Kyowa Hakko Kogyo) in 1.3 $\mathrm{M}$ sorbitol solution as previously reported $[13,16]$. Leaf protoplasts of $A$. alba were isolated in $1.2 \mathrm{M}$ sorbitol solution. Protoplasts of calluses originated from cotyledons and hypocotyls of $A$. alba were isolated using 1\% each of enzymes in $0.6 \mathrm{M}$ mannitol solution. After passing through a $95 \mu \mathrm{m}$ sized nylon mesh, protoplasts were purified by floatation in a density gradient centrifugation using $0.6 \mathrm{M}$ mannitol solution on $0.6 \mathrm{M}$ sucrose solution. They were washed with $0.6 \mathrm{M}$ mannitol solution three times by centrifugation at $300 \mathrm{~g}$ for $5 \mathrm{~min}$.

Protoplasts of $B$. sexangula were isolated from suspension cells cultured for $12-19$ days by $1 \%$ Cellulase RS and $0.25 \%$ Pectolyase Y-23 (Seishin) in $0.6 \mathrm{M}$ mannitol solution [12]. 
Protoplasts of cotyledons of $S$. alba were isolated in $1 \%$ each of Cellulase RS and Macerozyme R10 (Yakult) in $0.8 \mathrm{M}$ mannitol solution $[17,18]$. Protoplasts of suspension cells (9 - 19 days of culture) and callus (12 days of culture) were isolated in $1 \%$ each of Cellulase RS, Driselase 20 and Hemicellulase (Sigma H-2125) in $0.8 \mathrm{M}$ mannitol or sorbitol solution, then purified by floatation in density gradient centrifugation on $1 \mathrm{M}$ sucrose solution [18].

Protoplasts were purified with osmoticum solution by centrifugation at $100-300 \mathrm{~g}, 5 \mathrm{~min}$ after filtration through 42 - $95 \mu \mathrm{m}$ sized nylon mesh depending on the diameters of protoplasts. Numbers of protoplasts were counted using a hemocytometer. They were stored at $-80^{\circ} \mathrm{C}$ in $1.5 \mathrm{ml}$ micro-tubes or $1.2 \mathrm{ml}$ glass tubes after centrifugation.

\subsection{Amino Acid Analysis}

Amino acids were extracted and analyzed from tissues directly or from isolated protoplasts as reported by Ogita et al. [15]. Briefly, after extraction with $80 \%$ ethanol at $60^{\circ} \mathrm{C}$ three times, combined fractions were evaporated to dryness using a Vacuum centrifugal evaporator (CVE3100, EYELA, Tokyo Japan) with a glass cold trap (Uni trap UT-1000, EYELA). The residues were dissolved in $50 \mathrm{mM}$ borate buffer ( $\mathrm{pH} 8.0$, with $0.05 \mathrm{mM}$ EDTA). Amino acids were precolumn-derivatized with 4-fluoro7-nitrobenzo- $S$-oxa-1,3-diazole (NBD-F) [19] and analyzed using a gradient HPLC system (Gilson 305 system) at $30^{\circ} \mathrm{C}$. Column was YMC-Pack ODS-A reversed-phase column $(4.6 \mathrm{~mm} \times 150 \mathrm{~mm})$. Flow rate was $1.0 \mathrm{ml} / \mathrm{min}$. Fluorescence was measured at ex. $470 \mathrm{~nm}$, em. $540 \mathrm{~nm}$. Data were calculated from three different concentrations for each sample. And the data of two to four independently extracted samples were described as averages with standard errors in Tables 1-3.

\section{Results and Discussion}

As shown in Table 4, only a few mangrove species in each of the three different families had been successful in obtaining sub-culturable callus or suspension cultures and for cell divisions in protoplast cultures, using MS or

Table 1. Amino acid contents of mangrove cultured cells. Concentrations of amino acids are expressed as $\mathrm{nmol}^{-\mathrm{g}^{-1}}$ fresh weight or wet weight. The values in parenthesis show the percentage of total amino acids.

\begin{tabular}{|c|c|c|c|c|c|c|}
\hline $\begin{array}{l}\text { Amino } \\
\text { acids }\end{array}$ & $\begin{array}{c}\text { A. alba } \\
\text { Cotyledon-callus }\end{array}$ & $\begin{array}{c}\text { A. alba } \\
\text { Hypocotyl-callus }\end{array}$ & $\begin{array}{l}\text { B. sexangula } \\
\text { suspension }\end{array}$ & $\begin{array}{l}\text { S. alba } \\
\text { callus }\end{array}$ & $\begin{array}{c}\text { S. alba } \\
\text { suspension }\end{array}$ & $\begin{array}{l}\text { S. alba suspension } \\
\mathrm{NaCl} 50 \mathrm{mM}\end{array}$ \\
\hline His & $423 \pm 4(3)$ & $258 \pm 28(2)$ & $49 \pm 6(2)$ & $252(1)$ & $682(4)$ & $131 \pm 75(1)$ \\
\hline Arg & $906 \pm 39(6)$ & $938 \pm 104(9)$ & $93 \pm 24(3)$ & $997(6)$ & $628(3)$ & $30 \pm 1(0)$ \\
\hline Asn & $4258 \pm 1117(30)$ & $973 \pm 68(9)$ & $17 \pm 3(1)$ & $385(2)$ & $960(5)$ & $1372 \pm 1157(15)$ \\
\hline Gln & $1592 \pm 926(11)$ & $592 \pm 194(6)$ & $103 \pm 18(3)$ & $7573(45)$ & $5053(28)$ & $3026 \pm 507(33)$ \\
\hline Ser & $479 \pm 71(3)$ & $487 \pm 105(5)$ & $370 \pm 57(12)$ & $2423(14)$ & $2763(15)$ & $1031 \pm 35(11)$ \\
\hline Asp & $935 \pm 80(7)$ & $118 \pm 38(1)$ & $112 \pm 48(4)$ & $285(2)$ & $575(3)$ & $136 \pm 71(1)$ \\
\hline Gly & $1126 \pm 19(8)$ & $3046 \pm 137(29)$ & $52 \pm 10(2)$ & $134(1)$ & $256(1)$ & $75 \pm 10(1)$ \\
\hline Glu & $92 \pm 26(1)$ & $220 \pm 1(2)$ & $627 \pm 87(21)$ & $832(5)$ & $774(4)$ & $168 \pm 25(2)$ \\
\hline Thr & $176 \pm 20(1)$ & $109 \pm 15(1)$ & $74 \pm 26(2)$ & $4(0)$ & $19(0)$ & $0(0)$ \\
\hline Ala & $943 \pm 230(7)$ & $831 \pm 21(8)$ & $827 \pm 124(27)$ & $2498(15)$ & 2603 (14) & $2397 \pm 685(26)$ \\
\hline Pro & $189 \pm 38(1)$ & $870 \pm 146(8)$ & $126 \pm 50$ & $262(2)$ & $858(5)$ & $241 \pm 56(3)$ \\
\hline Met & $423 \pm 118(3)$ & $336 \pm 45(3)$ & $96 \pm 36(3)$ & $100(1)$ & $147(1)$ & $49 \pm 3(1)$ \\
\hline Val & $442 \pm 28$ & $264 \pm 57(3)$ & $68 \pm 12(2)$ & $244(1)$ & $685(4)$ & $152 \pm 5(2)$ \\
\hline (Cys)2 & $23 \pm 8(0)$ & $22 \pm 9(0)$ & $22 \pm 5(1)$ & $590(3)$ & $30(0)$ & $24 \pm 1(0)$ \\
\hline Lys & $521 \pm 3(4)$ & $438 \pm 75(4)$ & $73 \pm 22(2)$ & $87(1)$ & $447(2)$ & $38 \pm 2(0)$ \\
\hline Phe & $292 \pm 28(2)$ & $172 \pm 32(2)$ & $179 \pm 58(6)$ & $15(0)$ & $368(2)$ & $18 \pm 3(0)$ \\
\hline Ile & $477 \pm 8(3)$ & $237 \pm 34(2)$ & $39 \pm 16(1)$ & $111(1)$ & $330(2)$ & $84 \pm 5(1)$ \\
\hline Leu & $481 \pm 48$ & $360 \pm 94(3)$ & $53 \pm 13(2)$ & $140(1)$ & $352(2)$ & $109 \pm 12(1)$ \\
\hline Tyr & $209 \pm 5(1)$ & $122 \pm 12(1)$ & $38 \pm 9(1)$ & $44(0)$ & $482(3)$ & $20 \pm 2(0)$ \\
\hline
\end{tabular}


Table 2. Amino acid contents of protoplasts isolated from cultured cells. Concentrations of amino acids are expressed as nmol per $10^{7}$ protoplasts. The values in parenthesis show the percentage of total amino acids.

\begin{tabular}{|c|c|c|c|c|}
\hline Amino acids & $\begin{array}{l}\text { A. alba Cotyledon } \\
\text { callus PP }\end{array}$ & $\begin{array}{l}\text { A. alba Hypocotyl } \\
\text { callus PP }\end{array}$ & $\begin{array}{l}\text { B. sexangula } \\
\text { suspension PP }\end{array}$ & $\begin{array}{l}\text { S. alba suspension PP } \\
(\mathrm{NaCl} 50 \mathrm{mM})\end{array}$ \\
\hline His & $211 \pm 18(3)$ & $94(3)$ & $45 \pm 21(1)$ & $1551(5)$ \\
\hline Arg & $159 \pm 6(3)$ & $93(3)$ & $260 \pm 213$ & $646(2)$ \\
\hline Asn & $278 \pm 4(5)$ & $65(2)$ & $32 \pm 7(1)$ & $930(3)$ \\
\hline Gln & $1012 \pm 46(17)$ & $347(10)$ & $1851 \pm 424(32)$ & $15868(53)$ \\
\hline Ser & $335 \pm 6(6)$ & $193(6)$ & $600 \pm 86(10)$ & $1052(4)$ \\
\hline Asp & $33 \pm 10(1)$ & $9(0)$ & $43 \pm 17(1)$ & $314(1)$ \\
\hline Gly & $1226 \pm 88(20)$ & $238(7)$ & $35 \pm 12(1)$ & $337(1)$ \\
\hline Glu & $51 \pm 11(1)$ & $64(2)$ & $163 \pm 18(3)$ & $246(1)$ \\
\hline Thr & $204 \pm 30(3)$ & $75(2)$ & $145 \pm 54(2)$ & $617(2)$ \\
\hline Ala & $668 \pm 53(11)$ & $1103(32)$ & $1765 \pm 139(30)$ & $4457(15)$ \\
\hline Pro & $470 \pm 40(8)$ & $361(11)$ & $140 \pm 31(2)$ & $486(2)$ \\
\hline Met & $36 \pm 5(1)$ & $0(0)$ & $15 \pm 15(0)$ & $229(1)$ \\
\hline Val & $252 \pm 10(4)$ & $120(4)$ & $172 \pm 30(3)$ & $663(2)$ \\
\hline$(\mathrm{Cys}) 2$ & $45 \pm 21(1)$ & $10(0)$ & $0(0)$ & $635(2)$ \\
\hline Lys & $191 \pm 3(3)$ & $73(2)$ & $29 \pm 29(0)$ & $481(2)$ \\
\hline Phe & $155 \pm 10(3)$ & $63(2)$ & $66 \pm 32(1)$ & $220(1)$ \\
\hline Ile & $204 \pm 21(3)$ & $123(4)$ & $167 \pm 118$ & $250(1)$ \\
\hline Leu & $418 \pm 6(7)$ & $290(9)$ & $250 \pm 169$ & $733(2)$ \\
\hline Tyr & $88 \pm 54(1)$ & $84(2)$ & $85 \pm 41(1)$ & $213(1)$ \\
\hline total & $6034 \pm 92(100)$ & $3402(100)$ & $5863 \pm 1267(100)$ & $29,927(100)$ \\
\hline
\end{tabular}

(m)AA basal media.

In this report, in addition to the generation of callus cultures of $A$. alba from cotyledons, we were also successful in the generation of calluses from seedling hypocotyls (Figure 1(a)) using a mAA basal medium containing $1 \mu \mathrm{M}$ each of 2,4-D and TDZ, the same hormonal condition for the sub-culturing of cotyledon-derived suspension cells [10]. Callus proliferation from both tissues was observed after only one month, which is much faster than the previous induction of suspension cells from cotyledons in a mAA medium containing $1 \mu \mathrm{M}$ each of 2,4-D and benzyladenine, which took 5 months of culture. As shown in Figure 1, the calluses could be sub-cultured in the same composition medium as of induction and used for protoplast isolation and amino acid analysis. This is the first report on callus induction from hypocotyls of A. alba. Morphological characteristics of the callus cultures and their protoplasts derived from the hypocotyls (Figure 1) were similar to those of the cotyledonderived callus or suspension cells and their protoplasts

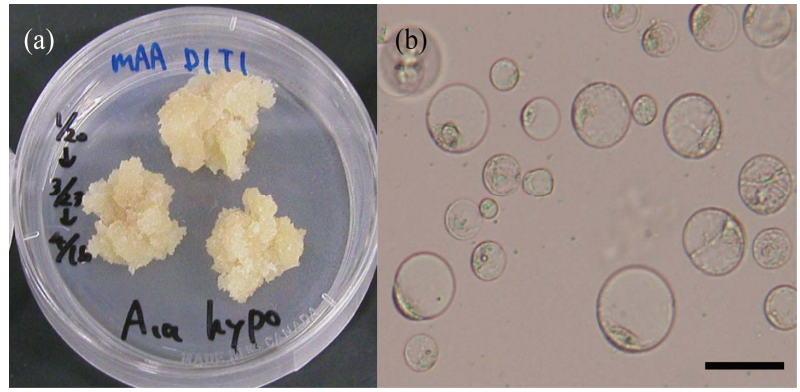

Figure 1. Hypocotyl derived callus (a) of Avicennia alba and their protoplasts (b). (a) sub-cultured callus in solid $\mathrm{mAA}$ basal medium containing $1 \mu \mathrm{M}$ each of 2,4-D and TDZ in a $6 \mathrm{~cm}$ petri dish. (b) isolated protoplasts in $0.6 \mathrm{M}$ mannitol solution. bar $=100 \mu \mathrm{m}$.

[13]. The method of storing seeds of A. alba in tap water at aseptic condition was based on the report on the cotyledon protoplast culture of crypto-viviparous seeds of $A$. marina [13]. Storing the seeds in pure water resulted in early browning of seeds of both Avicennia species. 
1370 Relation between Amino Acids Profiles and Recalcitrancy of Cell Growth or Salt Tolerance in Tissue and Protoplast Cultures of Three Mangrove Species, Avicennia alba, Bruguiera sexangula, and Sonneratia alba

Table 3. Amino acid contents of protoplasts isolated from leaves and cotyledons of mangrove plants. Concentrations of amino acids are expressed as $\mathbf{n m o l}$ per $10^{7}$ protoplasts. The values in parenthesis show the percentage of total amino acids.

\begin{tabular}{|c|c|c|c|c|c|}
\hline Amino acids & A. alba leaf PP & $\begin{array}{l}\text { A. alba } \\
\text { cotyledons PP }\end{array}$ & $\begin{array}{c}\text { A. lanata } \\
\text { cotyledons PP }\end{array}$ & $\begin{array}{c}\text { A. marina } \\
\text { cotyledons PP }\end{array}$ & $\begin{array}{c}\text { S. alba } \\
\text { cotyledons PP }\end{array}$ \\
\hline His & $17(0)$ & $1(0)$ & $41 \pm 2(1)$ & $186(2)$ & $795(4)$ \\
\hline $\operatorname{Arg}$ & $62(2)$ & $212(9)$ & $71 \pm 3(1)$ & $184(2)$ & $1229(6)$ \\
\hline Asn & $25(1)$ & $896(39)$ & $1282 \pm 157(18)$ & $3537(33)$ & $1237(6)$ \\
\hline Gln & $2246(56)$ & $54(2)$ & $1783 \pm 250(26)$ & $592(6)$ & $10215(52)$ \\
\hline Ser & $74(2)$ & $41(2)$ & $253 \pm 19(4)$ & $244(2)$ & $217(1)$ \\
\hline Asp & $24(1)$ & $27(1)$ & $260 \pm 68(4)$ & $281(3)$ & $83(0)$ \\
\hline Gly & $19(0)$ & $0(0)$ & $64 \pm 9(1)$ & $283(3)$ & $21(0)$ \\
\hline Glu & $58(1)$ & $68(3)$ & $166 \pm 15(2)$ & $200(2)$ & $253(1)$ \\
\hline Thr & $142(4)$ & $67(3)$ & $195 \pm 5(3)$ & $235(2)$ & $263(1)$ \\
\hline Ala & $630(16)$ & $342(15)$ & $1264 \pm 98(18)$ & $2489(23)$ & $1934(10)$ \\
\hline Pro & $138(3)$ & $85(4)$ & $99 \pm 5(1)$ & $199(2)$ & $439(2)$ \\
\hline Met & $0(0)$ & $0(0)$ & $0(0)$ & $43(0)$ & $113(1)$ \\
\hline Val & $119(3)$ & $68(3)$ & $497 \pm 19(7)$ & $502(5)$ & $401(2)$ \\
\hline (Cys) 2 & $17(0)$ & $0(0)$ & $0(0)$ & $34(0)$ & $95(0)$ \\
\hline Lys & $0(0)$ & $0(0)$ & $0(0)$ & $152(1)$ & $213(1)$ \\
\hline Phe & $48(1)$ & $62(3)$ & $231 \pm 18(3)$ & $261(2)$ & $672(3)$ \\
\hline Ile & $87(2)$ & $123(5)$ & $280 \pm 25(4)$ & $382(4)$ & $279(1)$ \\
\hline Leu & $271(7)$ & $168(7)$ & $357 \pm 19(5)$ & $764(7)$ & $747(4)$ \\
\hline Tyr & $55(1)$ & $71(3)$ & $130 \pm 110(2)$ & $182(2)$ & $419(2)$ \\
\hline total & $4030(100)$ & $2284(100)$ & $6972 \pm 87(100)$ & $10,750(100)$ & $19,625(100)$ \\
\hline
\end{tabular}

Table 4. List of mangrove species which were successful for sub-culturable callus cultures or suspension cultures, and for cell divisions in protoplast cultures.

\begin{tabular}{|c|c|c|c|c|c|}
\hline mangrove species & cultures & origin of cells & $\begin{array}{c}\text { origin of } \\
\text { protoplasts }\end{array}$ & $\begin{array}{l}\text { basal } \\
\text { medium }\end{array}$ & references in journals \\
\hline Sonneratia alba & callus & pistil & & MS & Akatsu et al. 1996 \\
\hline Sonneratia alba & callus, suspension cells & cotyledons & & MS & Kawana et al. 2007; Kawana \& Sasamoto 2008 \\
\hline Sonneratia alba & protoplast & - & cotyledons & MS & Kawana et al. 2009; Hasegawa et al. 2013 \\
\hline Sonneratia caseolaris & suspension cells & seedling & & MS & Yamamoto et al. 2009 \\
\hline Bruguiera sexangula & callus, suspension cells & leaf & & AA & Mimura et al. 1997; Kura-Hotta et al. 2001 \\
\hline Bruguiera sexangula & protoplast & - & suspension cells & MS & Fukumoto et al. 2004 \\
\hline Avicennia alba & suspension cells & cotyledons & & mAA & Hayashi et al. 2009 \\
\hline Avicennia alba & protoplast & - & suspension cells & mAA & Hasegawa et al. 2011, 2013 \\
\hline Avicennia alba & callus & cotyledons & & $\mathrm{mAA}$ & present report \\
\hline Avicennia alba & callus & hypocotyls & & $\mathrm{mAA}$ & present report \\
\hline Avicennia marina & protoplast & - & cotyledons & mAA & Hasegawa et al. 2011 \\
\hline
\end{tabular}


Table 1 shows amino acids contents of callus or suspension cells of $A$. alba, B. sexangula and $S$. alba expressed on a gram wet weight or fresh weight basis. Major amino acids in cotyledons-callus of $A$. alba were asparagine, glutamine and glycine, while glycine, asparagine, arginine, alanine and proline in hypocotyl-callus. In $S$. alba, there was no difference in amino acid profile between suspension cells and callus cultured in the media without $50 \mathrm{mM}$ of $\mathrm{NaCl}$; glutamine, alanine, serine were the major amino acids detected. When comparing the amino acid profiles between the suspension cells of $B$. sexangula and $S$. alba, major differences were observed in glutamine and glutamic acid levels. In S. alba suspension cells cultured in the medium containing $50 \mathrm{mM}$ of $\mathrm{NaCl}$, asparagine was also the major amino acid.

We also investigated the amino acid composition in the fresh and used medium of suspension culture of $B$. sexangula, which were cultured in AA basal medium. Though glutamine content in the fresh AA medium was already low $(281 \mu \mathrm{moles} / \mathrm{L}, 1 / 20$ of the expected amount $)$ after autoclaving at $120^{\circ} \mathrm{C}, 20 \mathrm{~min}$, arginine, aspartic acid, glycine contents were at expected values $(909,1556$, $1176 \mu$ moles/L, respectively). After 20 day of culture, a very low total content $(74 \mu$ moles/L, $2 \%$ of the fresh AA medium) was found in the used medium. Proline, serine and arginine $(20,17,11 \mu \mathrm{moles} / \mathrm{L}$, respectively) were major amino acids in the used medium and were different in suspension cells shown in Table 1. Amino acids in the AA medium were quickly taken up and metabolized by Bruguiera cells.

Though mAA basal medium contains arginine, aspartic acid and glutamine at high concentrations, very different amino acid profiles were noted in cotyledon- and hypocotyl-calluses of $A$. alba (Table 1). This indicates that both calluses of $A$. alba must have metabolized the medium amino acids during the course of culture.

Total amino acids contents of suspension cells of $B$. sexangula were lower than those of $A$. alba or $S$. alba (Table 1). Such low amino acid content of $B$. sexangula was repeatedly observed independent of culture period (2 to 3 weeks) of suspension cells. As the protoplasts are active to divide in culture, which were isolated from suspension cells of $B$. sexangula cultured for two-three weeks [12], metabolic activity of $B$. sexangula, e.g. protein synthesis, might remain active during the culture period. Low total amino acid content might be related to high activity of cell growth. B. sexangula suspension cells show salt tolerance; however, rapid growth can be obtained without additional salts while $S$. alba suspension cell cultures are halophilic [11]. In $S$. alba, the total amino acid content on the basis of $\mathrm{g}$ fresh (wet) weight of $\mathrm{NaCl}$-containing medium-grown suspension cells was half of the callus or suspension cells grown without addi- tional $\mathrm{NaCl}$. This phenomenon might reflect the halophilic nature found in S. alba suspension cells. In Avicennia, the reported values of total amino acid content in the mature plant organs, leaves or roots, of A. marina are very high $(68,329 \mu$ moles/g fresh weight) [20], compared to the values $(10-14 \mu$ moles $/ g$ fresh weight $)$ of the cultured cells of $A$. alba in Table 1.

Table 2 shows amino acids contents in $10^{7}$ protoplasts isolated from cultured cells of $A$. alba, $B$. sexangula, and S. alba. In A. alba callus-protoplasts, amino acid profiles were different between calluses induced from cotyledons and hypocotyls. Major amino acids were glycine, glutamine, alanine and proline in the former protoplasts while they were alanine, proline, glutamine and leucine in the latter. In protoplasts isolated from $S$. alba suspension cells cultured with $50 \mathrm{mM}$ of $\mathrm{NaCl}$, major amino acids were glutamine and alanine. In $B$. sexangula protoplasts, major amino acids were glutamine, alanine and serine.

Total amino acid contents in protoplasts from $A$. alba callus and $B$. sexangula suspension cells were similar. However, the total amino acid content in protoplasts from $S$. alba suspension cells grown in $\mathrm{NaCl}$-containing medium was very high. Such a high total amino acid content might reflect the recalcitrancy of protoplast culture of $S$. alba suspension cells [18,21].

From comparison between Tables $\mathbf{1}$ and $\mathbf{2}$, amino acid composition differs much between cultured cells and their protoplasts. In protoplasts and original cotyledoncallus of A. alba, glutamine content was similarly high; however, difference was observed in the contents of asparagines, alanine and proline. In protoplasts and original hypocotyl-callus of $A$. alba, alanine and proline contents were similarly high, however, difference was observed in the contents of arginine, asparagine, glutamine and glycine. In protoplasts and original suspension cells of $B$. sexangula, high alanine and high serine contents were similar each other. However, high glutamic acid content in suspension cells was different from high glutamine content in protoplasts. In $S$. alba, high contents of glutamine and alanine were similar to both protoplasts and suspension cells; however, high serine was only observed in suspension cells. These differences can be explained by the distribution of amino acids in cell wall of each cultured cells or by the metabolic changes of amino acids which might have occurred during protoplast isolation. Long incubation times, several hrs to 3 days, in strong enzymatic conditions are needed for isolation of protoplasts in mangrove species $[13,17]$. Therefore, such a difference in amino acids composition should affect culture conditions for them.

As reviewed in Table 4, some success in colony formation was already obtained in protoplast cultures of $S$. alba cotyledons [18] and A. alba suspension cells, and 
their halophilic or salt tolerant nature were found [14]. However, sub-culturable callus proliferation from protoplast culture was accomplished only with $B$. sexangula suspension cells [12]. Protoplast isolation and cultures of $S$. alba suspension cells were more difficult than that of cotyledons [21]. MS basal medium was used for all tissue cultured cells of $S$. alba, i.e. suspension cells and callus [5] and protoplasts cultures [14,18,21]. A. alba cotyledons-derived suspension cells preferred mAA basal medium to MS, similarly, in protoplast culture of them, colony formation was better in mAA basal medium than in MS [22]. Recently, at the optimal hormonal condition, $1 \mu \mathrm{M}$ each of 2,4-D and TDZ, cell enlargement and some cell divisions were obtained in protoplast cultures of hypocotyls-callus of $A$. alba in the same mAA basal medium as the medium for sub-culture of original callus [23]. In contrast, in the protoplast culture of B. sexangula, MS basal medium was preferred to (m)AA basal medium $[12,22]$, though AA was preferred to MS in callus culture [9]. Amino acid profile of the B. sexangula protoplasts showed the high glutamine content and the low glutamic acid content (Table 2) compared to those of suspension cells (Table 1).

Table 3 shows amino acids profiles of protoplasts of young leaf and cotyledons of Avicennia species, A. alba, A. lanata and A. marina, and cotyledons of $S$. alba. Higher total contents of amino acids were found in recalcitrant Avicennia species, A. lanata and A. marina, than $A$. alba, though the highest value was obtained in cotyledons of $S$. alba. In cotyledons of all three Avicennia species, asparagine and/or glutamine were the major amino acids, while glutamine was in cotyledons of $S$. $a l b a$ and young leaf of $A$. alba. Exclusively high asparagine content $(86 \%)$ in mature plant organs (leaf and root) of A. marina was reported [20]. In contrast, some value of alanine was obtained in protoplasts of all young tissues of Avicennia and Sonneratia species, and also in protoplasts of the suspension cells and callus of these species (Table 2). Such a difference in amino acids profiles might reflect the recalcitrance of mature organs for induction of callus and suspension cell cultures compared to young tissues, e.g. cotyledons and hypocotyls of a seedling. Endogenous levels of specific amino acids, e.g. glutamine, are important for the maintenance of recalcitrant conifer callus cultures [15]. However, only high glutamine content is not sufficient for induction of callus in recalcitrant mangrove tissues.

Proline is one of amino acids which is known to relate to stress tolerance and used in tissue culture [24]. High proline content along with high content of osmoregulator (glycinebetaine) was reported in protoplasts of cotyledons of A. marina [25]. Low proline data of A. marina shown in Table 3 might be caused by the long seed- storage period in tap water in this report. During the long storage time, the endogenous content of stress-related plant hormone, abscisic acid, also decreased and some cell enlargement and cell divisions were observed in protoplast culture [13]. Genes related to proline utilization in A. marina was reported [26], though no proline was detected in mature plant organs of it [20]. In this report, proline was present in A. alba hypocotyl-derived callus and protoplasts of cotyledon-derived callus and it did not totally inhibit growth of them.

By investigation of the differences between wall containing suspension cells and protoplasts, we can know the site of precise mechanisms for halophillic or salt tolerance and the osmotic tolerance in mangrove cells [14]. From the total amino acid data on wet weight basis shown in Table 1, ca. $10-20 \mathrm{mM}$ concentration was calculated for $S$. alba suspension cells. Protoplasts are simple system; removing cell walls, under osmotic pressure, are spherical shaped and cell numbers can be counted easily, while suspension cells or callus are difficult to measure their cell numbers. Volume of $10^{7}$ protoplasts can be calculated from their diameters, i.e. $42 \mu \mathrm{L}$ $(20 \mu \mathrm{m}), 141 \mu \mathrm{L}(30 \mu \mathrm{m})$ and $393 \mu \mathrm{L}(50 \mu \mathrm{m})$. The concentrations of endogenous plant hormones in a protoplast were calculated in conifer protoplasts [27]. Similarly, as diameter of protoplasts of $S$. alba suspension cells was 30 to $50 \mu \mathrm{m}$ [18], total amino acid concentration of them was calculated to be $150 \mathrm{mM}$ at the highest when amino acids distribute uniformly in a cell. Considering some compartmentation in organelles of a protoplast, a part of osmotic adjustment might be regulated by amino acids and might contribute to the halophilic nature of $S$. alba cells. Lower values of total amino acid concentration were calculated for other materials.

\section{Conclusions}

Callus cultures of A. alba were induced from cotyledons and hypocotyls, respectively, of small seedlings in a mAA basal medium containing $1 \mu \mathrm{M}$ each of 2,4-D and TDZ. This is the first report on callus induction from hypocotyls of $A$. alba.

Amino acids profiles were investigated in tissues, in cultured cells, i.e. callus or suspension cells, and in their protoplasts of three mangrove species, Avicennia alba, Bruguiera sexangula, and Sonneratia alba. Large differences in major amino acids were found among cultured cells and their protoplasts while no difference was found between callus and suspension cells nor between cells cultured with or without $\mathrm{NaCl}$ in $S$. alba. In suspension cells of $B$. sexangula, which were sub-cultured in AA basal medium, total contents of amino acids were low and glutamic acid was observed along alanine and serine. Low total amino acid content which might reflect high 
metabolic activity can be related to the success of subculturable callus culture or suspension culture of mangrove species. In protoplasts isolated from cultured cells of the three mangrove species, glutamine and alanine were the major amino acids. Different contents of glycine, proline and serine were observed among protoplasts. In $B$. sexangula protoplasts, which were successful for protoplast culture in MS basal medium, high glutamine content was observed. Amino acid profiles and contents in protoplasts of original tissues, leaves and cotyledons of $A$. $a l b a$ and cotyledons of $S$. alba, were compared to those of recalcitrant mangrove species, A. lanata and A. marina. Cotyledons of all three Avicennia species contained asparagine and/or glutamine and alanine, while cotyledons of $S$. alba and young leaf of $A$. alba contained glutamine and alanine. They were very different from the report of mature organ of A. marina, which were recalcitrant for culture.

The total contents of amino acids and their profiles might be related to the recalcitrance for the growth and salt tolerance or halophilic nature of cells and basal media used for the maintenance of cell cultures or protoplast cultures of the mangrove species.

\section{Acknowledgements}

Authors thank to Dr. Reiko Minagawa for supplying the seeds of Avicennia alba and A. lanata, and thank to Prof. Edward C. Yeung of the University of Calgary for his valuable suggestions on this ms.

\section{REFERENCES}

[1] P. B. Tomlinson, "The Botany of Mangroves," Cambridge University Press, New York, 1986.

[2] M. Spalding, M. Kainuma and L. Collins, "World Atlas of Mangroves," Gutenberg Press, Malta, 2010.

[3] S. Ogita, E. C. Yeung and H. Sasamoto, "Histological Analysis in Shoot Organogenesis from Hypocotyl Explants of Kandelia candel (L.) Druce," Journal of Plant Research, Vol. 117, No. 6, 2004, pp. 457-464. doi:10.1007/s10265-004-0180-4

[4] M. Akatsu, Y. Hosoi, H. Sasamoto and H. Ashihara, "Purine Metabolism in Cells of a Mangrove Plant, Sonneratia alba, in Tissue Culture," Journal of Plant Physiology, Vol. 149, No. 1-2, 1996, pp. 133- 137. doi:10.1016/S0176-1617(96)80185-4

[5] Y. Kawana, R. Yamamoto, Y. Mochida, K. Suzuki, S. Baba and H. Sasamoto, "Generation and Maintenance of Suspension Cultures from Cotyledons and Their Organogenic Potential of Two Mangrove Species, Sonneratia alba and S. caseolaris," Plant Biotechnology Reports, Vol. 1, No. 4, 2007, pp. 219-226. doi:10.1007/s11816-007-0035-2

[6] R. Yamamoto, Y. Kawana, R. Minagawa and H. Sa- samoto, "Effects of Carbon and Nitrogen Sources on Induction of Cell Proliferation in Tissue Cultures of a Mangrove Plant, Sonneratia caseolaris," Mangrove Science, Vol. 6, 2009, pp. 1-8.

[7] T. Murashige and F. Skoog, "A Revised Medium for Rapid Growth and Bioassay with Tobacco Tissue Cultures," Physiologia Plantarum, Vol. 15, 1962, pp. 473497. doi:10.1111/j.1399-3054.1962.tb08052.x

[8] M. Kura-Hotta, M. Mimura, T. Tsujimura, S. Washitani-Nemoto and T. Mimura, "High Salt-Treatment-Induced $\mathrm{Na}+$ Extrusion and Low Salt-Treatment-Induced $\mathrm{Na}+$ Accumulation in Suspension-Cultured Cells of the Mangrove Plant Bruguiera sexangula," Plant Cell Environment, Vol. 24, No. 10, 2001, pp. 1105-1112. doi:10.1046/j.0016-8025.2001.00761.x

[9] T. Mimura, M. Mimura, S. Washitani-Nemoto, K. Sakano, T. Shimmen and S. Siripatanadilok, "Efficient Callus Initiation from Leaf of Mangrove Plant, Bruguiera sexangula in Amino Acid Medium: Effect of $\mathrm{NaCl}$ on Callus Initiation," Journal of Plant Research, Vol. 110, No. 1, 1997, pp. 25-29. doi:10.1007/BF02506839

[10] S. Hayashi, S. Kuriyama, Y. Kawana, A. Hasegawa, A. Kurita, R. Minagawa and H. Sasamoto, "Stimulatory Effects of Sea Salts on Cell Growth in Liquid Culture of Avicenniaceae Mangrove," Plant Biotechnology, Vol. 26, No. 5, 2009, pp. 561-564. doi:10.5511/plantbiotechnology.26.561

[11] Y. Kawana and H. Sasamoto, "Stimulation Effects of Salts on Growth in Suspension Culture of a Mangrove Plant, Sonneratia alba, Compared with Another Mangrove, Bruguiera sexangula and Non-Mangrove Tobacco BY-2 Cells," Plant Biotechnology, Vol. 25, No. 2, 2008, pp. 151-155. doi:10.5511/plantbiotechnology.25.151

[12] T. Fukumoto, T. Nakamura, M. Suzuki, S. Ogita, T. Mimura and H. Sasamoto, "Different Effects of Four Salts and $\mathrm{pHs}$ on Protoplast Cultures of a Mangrove, Bruguiera sexangula Suspension Cells, Populus alba Leaves and Tobacco BY-2 Cells," Plant Biotechnology, Vol. 21, No. 3, 2004, pp. 177-182. doi:10.5511/plantbiotechnology.21.177

[13] A. Hasegawa, S. Hayashi, A. Kurita, F. Kaai, Y. Kawana, T. Fukumoto and H. Sasamoto, "Stimulatory and Inhibitory Effects of Abscisic Acid on Cell Growth in Protoplast Cultures and the Relation to Its Endogenous Levels in Avicenniaceae Mangrove Cells," Mangrove Science, Vol. 8, 2011, pp. 11-18. doi:10.1007/s11816-012-0251-2

[14] A. Hasegawa, A. Kurita, S. Hayashi, T. Fukumoto and H. Sasamoto, "Halophilic and Salts Tolerant Protoplast Cultures of Mangrove Plants, Sonneratia alba and Avicennia alba," Plant Biotechnology Reports, Vol. 7, No. 2, 2013, pp. 205-209. doi:10.1007/s11816-012-0251-2

[15] S. Ogita, H. Sasamoto, E. C. Yeung and T. A. Thorpe, "The Effects of Glutamine on the Maintenance of Embryogenic Cultures of Cryptomeria japonica," In Vitro Cellular and Developmental Biology Plant, Vol. 37, No. 2, 2001, pp. 268-273. doi:10.1007/s11627-001-0048-4

[16] H. Sasamoto, Y. Wakita and S. Baba, "Effect of High Sorbitol Concentration on Protoplast Isolation from Coty- 
ledons of Mangroves, Avicennia marina, and A. lanata," Plant Biotechnology, Vo. 14, No. 2, 1997, pp. 101-104. doi:10.5511/plantbiotechnology.14.101

[17] Y. Kawana, H. Sasamoto, Y. Mochida and K. Suzuki, "Leaf Protoplast Isolation from Eight Mangrove Species of Three Different Families; Avicenniaceae, Rhizophoraceae and Sonneratiaceae," Mangrove Science, Vol. 3, 2004, pp. 25-31.

[18] Y. Kawana, F. Kaai and H. Sasamoto, "Abscisic Acid Stimulates Cell Divisions in Cultures of Protoplasts Isolated from Cotyledons and Suspension Cells of a Mangrove Plant Sonneratia alba: Small-Scale Measurements of Abscisic Acid and Gibberellins in Protoplasts," Mangrove Science, Vol. 6, 2009, pp. 9-15.

[19] H. Kotaniguchi and M. Kawakatsu, "Automatic Amino Acid Analysis Utilizing 4-Fluoro-7-nitobenzo-s-oxa-diazole," Journal of Chromatography, Vol. 420, 1987, pp. 141-145.

[20] H. Ashihara, K. Adachi, M. Otawa, E. Yasumoto, Y. Fukushima, M. Kato, H. Sano, H. Sasamoto and S. Baba, "Compatible Solutes and Inorganic Ions in the Mangrove Plant, Avicennia marina and Their Effects on the Activities of Enzymes," Zeitshrift fur Naturforschung, Vol. 52c, 1997, pp. 433-440.

[21] A. Hasegawa, S. Hayashi, A. Kurita, Y. Kawana, T. Fukumoto and H. Sasamoto, "Isolation and Cultures of Suspension Cells of Sonneratia alba: Development of Bioassay Method of Allelopathy at Cellular Levels," $A b$ stracts of 14th MTG of Japanese Mangrove Society, 2008, p. 14.

[22] A. Kurita, S. Kuriyama, Y. Kawana and H. Sasamoto,
"Characteristics of Basal Medium for Suspension Cultures and Their Protoplasts Cultures of Avicennia alba and Bruguiera sexangula," Abstracts of $13 \mathrm{th} \mathrm{mtg}$ of Jpn Mangrove Society, 2007, p. 6.

[23] S. Tsuchiya, R. Minagawa, A. Inoue and H. Sasamoto, "Development of Cell Culture System from Hypocotyls of Avicennia alba: Callus Proliferation and Their Protoplasts Isolation and Cultures," Abstracts of 16th MTG of Japanese Mangrove Society, 2010, p. 15.

[24] C. N. Chowdhry, A. K. Tyagi, N. M. Maheshwari and S. C. Maheshwari, "Effect of 1-Proline and 1-Tryptophan on Somatic-Embryogenesis and Regeneration of Rice (Oryza sativa L. cv. Pusa169," Plant Cell Tissue and Organ Culture, Vol. 32, No. 3, 1993, pp. 357-361. doi:10.1007/BF00042300

[25] S. Ogita, H. Sasamoto, H. Ashihara and S. Baba, "Levels of Glycinebetaine and Amino Acids in Cotyledons Protoplasts of a Mangrove, Avicennia marina," Proceedings of 111th MTG of Japanese Forest Society, 2000, p. 604.

[26] R. Waditee, T. Hibino, Y. Tanaka, T. Nakamura, A. Incharoensakdi, S. Hayakawa, S. Suzuki, Y. Futsuhara, Y. Kawamitsu, T. Takabe and T. Takabe, "Functional Characterization of Betaine/Proline Transporters in BetaineAccumulating Mangrove," Journal of Biological Chemistry, Vol. 277, 2002, pp. 18373-18382. doi:10.1074/jbc.M112012200

[27] H. Sasamoto and S. Ogita, "Endogenous Plant Hormones in Protoplasts of Embryogenic Cells of Conifers," In: N. Morohoshi and A. Komamine, Eds., Molecular Breeding of Woody Plants, Elsevier Science, Amsterdam, 2001, pp. 279-288. 